\title{
Plant species dominance shifts across erosion edge-meadow transects in the Swiss Alps
}

\author{
Corinne Huck • Christian Körner • Erika Hiltbrunner
}

Received: 2 May 2012/Accepted: 18 December 2012/Published online: 22 January 2013

(C) Springer-Verlag Berlin Heidelberg 2013

\begin{abstract}
While exerting no obvious function under "average" environmental conditions, the presence of certain plant specialists becomes crucial in the event of a complete failure of a community due to severe disturbance such as landslides. Plants capable of growing at erosion edges may act as potential edge-engineers by coping with unstable ground and stabilizing the soil with their roots. We hypothesized that life conditions at erosion edges select for a particular set of specialists or species with specific traits, the identification of which was the aim of the study. Across 17 small-scale transects $(0.40 \times 1.60 \mathrm{~m})$ from intact meadows to landslide edges (Ursern Valley, Swiss Alps, c. 1,600 $\mathrm{m}$ a.s.l.), we quantified plant species abundance by the point intercept method and characterized growth conditions based on Landolt's indicator values, leaf $\delta^{13} \mathrm{C}$, and volumetric soil moisture in the uppermost soil layers. We observed a clear change of plant species composition and relative abundance from the meadow to the edge, presumably induced by the $25 \%$ lower soil moisture and microclimatic exposure. Species richness at the edge was two-thirds of that in the meadow, but was positively correlated with species richness of the adjacent meadow. Species with "edge-preference" had either (1) rolled or festucoid leaves like Festuca spp., Avenella flexuosa and Nardus stricta, or (2) small, scleromorphic leaves like
\end{abstract}

Communicated by Russell Monson.

Electronic supplementary material The online version of this article (doi:10.1007/s00442-012-2583-6) contains supplementary material, which is available to authorized users.

C. Huck · C. Körner · E. Hiltbrunner $(\bowtie)$

Institute of Botany, University of Basel, Schönbeinstrasse 6, 4056 Basel, Switzerland

e-mail: erika.hiltbrunner@unibas.ch
Vaccinium vitis-idaea, Calluna vulgaris and Thymus ssp. Graminoids with rolled/festucoid leaves were found to be the most dominant edge-specialists. The grass Festuca valesiaca s.l. emerged as the most dominant plant species at the edge, having an 11-times higher cover at the edge than in the meadow. In this montane grassland, a single species contributes to the stabilization of erosion edges and may be regarded as a potential keystone species for slope stability and regeneration after landslides even its role has not so far been established.

Keywords Festuca valesiaca s.l. · Landslide · Plant diversity $\cdot$ Slope stability $\cdot$ Soil moisture gradient

\section{Introduction}

Loss of soil substrate due to erosion following from mismanagement is among the most severe components of global change (Morgan 2005). One particular form of erosion on steep slopes in humid regions represents landslides. Landslides and associated debris flows are an integral part of natural landscape dynamics in mountains, although often increased by land use (Maquaire and Malet 2006). The land area eroded by landslides in the study area (in particular, the southern slopes) has increased by $92 \%$ during only the last 50 years, largely because of a massive increase in animal livestock of cattle and sheep (Meusburger and Alewell 2008). The landslide events themselves are often triggered by long-lasting intense precipitation or moisture loading during snow melt (Rickli and Graf 2009). For instance, a long-lasting rain event of $270 \mathrm{~mm}$ within 3 days in November 2002 triggered at least 17 landslides in the study area (Meusburger and Alewell 2008), allowing us to select landslides with a "known" age. Soil type, slope 
inclination, climate, and extreme rainfall events, but also vegetation (cover, species composition, and rooting pattern) contribute to landslide risk (Morgan 2005; Maquaire and Malet 2006). Plants affect properties of the soil, such as infiltration rate, aggregate stability, moisture content, shear strength, and organic matter content, which in turn control erosion rates to various degrees (Styczen and Morgan 1995; Gyssels et al. 2005). The soil re-inforcement provided by plants strongly depends on morphological characteristics of the root system and their tensile strength (Reubens et al. 2007; De Baets et al. 2008; Stokes et al. 2009; Pohl et al. 2011). A higher root density as a result of higher plant species diversityhas a positive effect on soil aggregate stability (Pohl et al. 2009; Fattet et al. 2011). Hence, a dense and morphologically diverse plant cover is essential for slope stability and soil conservation (Körner 2004).

During recent years, evidence accumulated that a large pool of species, thus, high biodiversity, is required to ensure the stability of ecosystems besides the provision of manifold ecosystem products and services (Tilman and Downing 1994; Naeem et al. 1995; Wohl et al. 2004; Proulx et al. 2010). In theory, there are three main hypotheses relating to how biodiversity has an effect on ecosystem functions referring to slope stability: (1) "niche complementarity" hypothesis implies that more species use available resources more efficiently (Loreau and Hector 2001) and, therefore, contributing to the general robustness of a community, (2) "probability/selection hypothesis" (Loreau and Hector 2001) accounts for the greater probability of a community with high species diversity to contain a 'keystone' species; a keystone species affects community and/or ecosystem processes to a degree that appears greater in the sense of effectiveness than its relative abundance or biomass in a community indicates (Bond 1993; Mills et al. 1993); and, similar to the keystone concept, (3) the "insurance hypothesis" which postulates that greater species richness insures the ecosystem against failure in the long term, because a higher species number enlarges the probability that some species will remain functioning even if others fail (Yachi and Loreau 1999; Loreau et al. 2001; Naeem et al. 2009). The difficulty of these three hypotheses is that the principles or action mechanisms they describemay not become effective under standard environmental conditions. Often, it is only under extreme events that the beneficial contribution of high species richness to ecosystem functions or the specific role and traits of a species become evident and, thus, perceptible.

The importance of species-rich meadows, which have a higher probability of containing species with particular traits, may become apparent in cases of disturbance by erosion events such as landslides. Life conditions on the landslide scar, but also at the edges of landslides, may demand specific traits that are crucial for surviving under such harsh conditions. Such specialist species would best be contained in the meadow species pool, since the seed bank within the eroded zones of the landslides is commonly poor (Chambers et al. 1990; Chambers 1995; Nagel 2009).

We consider stable edges to be crucial for preventing progressive widening of the eroded area and for the revegetation process. Landslides can be subjected to high rates of soil erosion long after the initial disturbance leading to large erosion gullies (Chaudhry et al. 1996; Walker and Shiels 2008). Since the topsoil is disrupted or the edges remain unstable, more and more sods slide down at existing landslide scars (Auerswald 1998). The stability of erosion edges strongly depends on plants that can cope with the conditions at the edge, enhancing soil cohesion and, thus, slowing down erosion.

The soil at the landslide edge is much more exposed to solar radiation and wind than the soil in the meadow. Since high levels of radiation and wind speed are often coupled with topsoil dryness (Larcher 2003), we expect the soil at the erosion edge to be drier than in the meadow. Drought impact selects for certain species and traits, and thus may rapidly change community structure (Allen-Diaz 1991; Kluse and Diaz 2005). Therefore, we expect species composition to change towards the erosion edge, as was found in a comparable study at the edges of erosion gullies in the Central Caucasus (Caprez et al. 2011).

The objectives of this study were to characterize the ecological conditions at landslide erosion edges in montane grassland of the Swiss central Alps, and to analyze species composition across small-scale transects from the erosion edge into the meadow. Since drought is likely to be the most selective force at the edge, we studied drought responses in the leaves of the three most abundant species. The aim was to identify the most successful plant species at erosion edges; hence, we were looking for potential "edge-engineers" and their specific traits in the local species pool.

\section{Materials and methods}

\section{Study site}

The study area is located on the southern slope of the Ursern Valley (Swiss central Alps, $46^{\circ} 36^{\prime}-46^{\circ} 37^{\prime} \mathrm{N}, 8^{\circ} 30^{\prime}-$ $8^{\circ} 34^{\prime} \mathrm{E}$ ). In this wide, glacial W-E valley, elevations range from 1,400 to $3,200 \mathrm{~m}$ a.s.l., and the predominant slope angle is approximately $27^{\circ}$ (Meusburger and Alewell 2008). At lower elevations, the growing season (daily temperature mean $>5^{\circ}$ ) lasts from the end of May to early October. Annual precipitation reaches ca. $1,500 \mathrm{~mm}$ in 
Gütsch above the village of Andermatt, 2,287 $\mathrm{m}$ a.s.l. (Meteo-Schweiz 1990-2007). Due to medieval land use, the valley was already deforested by the eleventh century (Kägi 1973; Küttel 1990b), and since then it has been under intense use for hay making and pasturing. On the less productive, wetter north-facing slope Alnus viridis (green alder) has become dominant as a result of land abandonment (Küttel 1990a). The southern slopes are still under use for both mowing and grazing (cattle and sheep). However, these slopes have seen massive erosion by landslides during the last 50 years, largely due to grazing intensification (Meusburger and Alewell 2008).

The current study was carried out at the edges of 14 landslides on the southern slope of the Ursern Valley at elevations ranging from 1,550 to $1,620 \mathrm{~m}$ a.s.1. The majority of the investigated landslides (12 out of 14) dated from the year 2002 and the other 2 from 2004. Landslides were separated by at least $50 \mathrm{~m}$ (Swisstopo 2006). The almost identical age of the selected landslides allowed us to consider each of the landslides as a spatial replicate and minimized how plant composition was affected by varying durations of the re-vegetation process, particularlyat the edges. The average size of the landslides was c. $10 \times 20 \mathrm{~m}$, and the vertical relief from the level of the intersected meadow was approximately $0.5-1 \mathrm{~m}$. A total of 17 plots (i.e. small-scale transects) was defined from the edges to the meadows, bordering the edges of these 14 landslides (not more than one plot per side edge). The criteria for choosing the position of test plots werea straight side edge on a length of at least $1.6 \mathrm{~m}$. All plots $(0.4 \times 1.6 \mathrm{~m}$; Fig. S1) were fenced (fenced area: $\mathrm{c}$. $3 \times 4 \mathrm{~m}$ ) in order to prevent grazing or mowing in the year of the study (2008).

Soil moisture and vegetation measurements

Soil moisture was measured at $0-6 \mathrm{~cm}$ soil depth in $5-\mathrm{cm}$ intervals over a distance of $40 \mathrm{~cm}$ ( 2 transects per each plot) on three different dates (18 June, 1 and 24 July 2008) using a Theta Probe (Delta-T Devices, Cambridge, UK) connected to a handheld meter.

Vegetation cover was measured on a transect from the edge of the landslide into the undisturbed meadow applying the point intercept method (Bonham 1989). In each plot, 20 parallel transects of $40 \mathrm{~cm}$ length were placed in intervals of $8 \mathrm{~cm}$, perpendicularly to the edge (Fig. S1). To visualize the transects, a thin cord with marks every $1 \mathrm{~cm}$ was stretched across the vegetation. A pin was lowered every $\mathrm{cm}$ at a constant angle and the first hit of the pin was recorded (plant species or bare soil). Thus, a total of 820 points per each plot described the vegetation cover at the beginning of the peak flowering season end June/ early July 2008. The vegetation height and the aboveground phytomass were obtained from a $25 \times 40 \mathrm{~cm}$ subplot within each of the 17 plots. Aboveground phytomass was harvested at end-July/early August in intervals of $5 \mathrm{~cm}$ starting at the edge, to a distance of $40 \mathrm{~cm}$. Phytomass was separated in biomass and necromass (dead, attached plant material), and biomass was additionally sorted by species. Before weighing, the samples were dried at $80{ }^{\circ} \mathrm{C}$ for at least $48 \mathrm{~h}$.

Plant nomenclature followed the Swiss flora of Binz and Heitz (1990). Festuca spp. was determined by using microscopic leaf cross-sections. By far the most frequent Festuca species was $F$. trachyphylla (Hackel) Krajina, belonging to the $F$. valesiaca Schleicher ex Gaudin aggregate (subsequently referred to as "Festuca valesiaca s.l."). In the following, the term "edge" is used for $0-5 \mathrm{~cm}$ distance from the edge and the term "meadow" is applied to $35-40 \mathrm{~cm}$ distance from the edge.

\section{Vegetation analysis}

Species were classified into functional groups according to physiomorphotypic characteristics (Körner 1993; ordered alphabetically): dwarf shrubs, graminoids with rolled/festucoid leaves (i.e. Festuca valesiaca s.1., F. rubra s.1., F. ovina s.l., Avenella flexuosa, Nardus stricta), graminoids with non-rolled leaves (Poaceae, Juncaceae, Cyperaceae), N-fixing forbs and non-N-fixing forbs. Rolling of leaves, i.e. reducing the transpiring leaf surface as well as the presence of stomata inside the rolled, adaxial leaf side, are commonly considered as an adaptive leaf trait to dry environmental conditions (Redmann 1985).

Landolt values (Landolt 1977), i.e. ecological indices that characterize plants according to their environmental preferences, were used to describe the ecological conditions across the edge to meadow transect. Six soil and climate factors are distinguished: soil moisture, soil reaction $(\mathrm{pH})$, soil fertility, light, temperature, and continentality; 1 indicates a preference for low values of a factor and 5 a preference for high values of a factor. In this study, weighted community means of the Landolt values (i.e. weighted by relative abundance of each species) were calculated for species growing at the edge (0-5) and in the meadow (35-40 cm from the edge), based on the vegetation cover data.

The Jaccard's index of similarity (Jaccard 1908) was used to test whether the vegetation among the edges of the different plots was more similar than the vegetation within one plot (vegetation at the very edge compared to the vegetation further into the meadow). The Jaccard's index describes the similarity between two samples based on the 
following equation ( $J=1$ means complete similarity, $J=0$ means complete dissimilarity):

$J_{(A, B)}=\frac{c}{a+b-c}$

where $a$ and $b$ are the number of species in sample $A$ and $B$, respectively, and $c$ is the number of species shared by the two samples. In this study, we compared the mean Jaccard indices for each edge $(0-5 \mathrm{~cm}$ distance from the edge) to the other edges as well as to the indices of the corresponding meadow ( $35-40 \mathrm{~cm}$ distance from the edge). The Jaccard indices were calculated from the species lists, resulting from the point intercept assessment.

An edge index allowed to classify all plant species observed into species with edge preference (values from 0 to +1 ) and species with meadow preference (values from -1 to 0$)$, respectively.

Edge index $=\frac{\left(n_{\text {edge }}-n_{\text {meadow }}\right)}{\left(n_{\text {edge }}+n_{\text {meadow }}\right)}$

$n_{\text {edge }}$ is the number of times a species was found at $0-5$ $\mathrm{cm}$ distance from the edge, while $n_{\text {meadow }}$ is the number of times a species was found at $35-40 \mathrm{~cm}$ distance from the edge. Species that were not present in either of the two categories had an edge index of 0 . Theoretically, species that occur equally often at the edge and in the meadow also have an edge index of 0 (however, this was not observed for any of the species). This index was calculated based on the vegetation cover data.

\section{Drought effect analysis}

Leaf expansion rates and resulting leaf lengths, especially in grass species, are known to be sensitive to water stress (Busso and Richards 1993; Sadras and Milroy 1996). In order to test if plants growing at the edge are affected by drought conditions, leaf length and $\delta^{13} \mathrm{C}$ of leaf samples were measured in the three most abundant species Festuca valesiaca s.1., Brachypodium pinnatum (L.) P.B. and $A g$ rostis gigantea Roth. Since the three species were not present or not frequent enough in all test plots, measurements for Festuca valesiaca s.l. were carried out in nine plots, for B. pinnatum in 11 plots, and for A. gigantea in eight plots. The longest leaf of each of seven individuals at 0-10 cm distance from the edge and of each of seven individuals within a distance of $>35 \mathrm{~cm}$ from the edge was collected in mid-July. Leaf length was averaged per plot before statistical analysis. At the same time, in each plot, leaf samples of four individuals at $0-10 \mathrm{~cm}$ distance (pooled per edge for each plot) and of four individuals at $>35 \mathrm{~cm}$ distance from the edge were taken for the $\delta^{13} \mathrm{C}$ analysis (pooled per meadow within each plot). Per single individual (two to) four leaves were collected (cf. Caldeira et al. 2001). All samples were dried at $80^{\circ} \mathrm{C}$ for at least 48 h. Leaf samples were ball-milled and analyzed for $\delta^{13} \mathrm{C}$ in an isotope ratio mass spectrometer (Delta-S; Finnigan, Bremen, Germany) in the laboratory of the Paul Scherrer Institute (PSI) in Villigen, Switzerland. The delta $(\delta)$ notation expresses the abundance of the heavier stable isotope $\left({ }^{13} \mathrm{C}\right)$ in a mixture of atoms relative to an international standard (V-PD belemnite). $\delta^{13} \mathrm{C}$ values in \%o were calculated using the following equation:

$\delta^{13} \mathrm{C}=\left[\frac{\left(\frac{{ }^{13} C}{{ }^{12} C}\right)_{\text {sample }}}{\left({ }^{13} C\right)_{\text {standard }}-1}\right] * 1000$

The more negative the $\delta^{13} \mathrm{C}$ value, the less of the heavier isotope ${ }^{13} \mathrm{C}$ is present in the sample. Under drought stress, the stomata are closed, the intercellular $\mathrm{CO}_{2}$ concentration decreases and the enzyme Rubisco discriminates less against ${ }^{13} \mathrm{CO}_{2}$. Therefore, plant tissue that experiences long-term drought stressshows less negative $\delta^{13} \mathrm{C}$ values (Dawson et al. 2002).

Statistical analysis

Appropriate regression models were applied to the cover of each functional group (regression models, see Table 2), cover of the three most abundant plant species [Festuca valesiaca s.l. (exponential regression), Brachypodium pinnatum (quadratic regression), Agrostis gigantea (quadratic regression), and species richness (quadratic regression)]. Soil moisture, vegetation height, total biomass and necromass, and thew biomass of the three most abundant species were analyzed by one-way ANOVAs and subsequent Tukey tests. Vegetation height data was logtransformed and biomass data of the three most abundant species were arcsine-transformed for the statistical analysis. Paired $t$ tests were carried out to analyze the difference between edge and meadow of leaf length, $\delta^{13} \mathrm{C}$, and the Landolt indicator values. Jaccard indices were compared using an unpaired $t$ test. The Pearson's product moment correlation coefficient was calculated to test the correlation between species richness of edge and meadow. All statistical analysis was performed using the software R 2.7.2 (R Development Core Team 2008). Differences are statistically significant at: $* * * p<0.001 ; * * p<0.01 ; * p<0.05$.

\section{Results}

General characteristics of the edge-meadow transect

Precipitation sums of the 2 weeks preceding the soil moisture measuring dates were $57 \mathrm{~mm}$ for 18 June, $44 \mathrm{~mm}$ for $1 \mathrm{July}$, and $114 \mathrm{~mm}$ for 24 July. During the 2 weeks preceding the measuring dates, there were 14 days with 


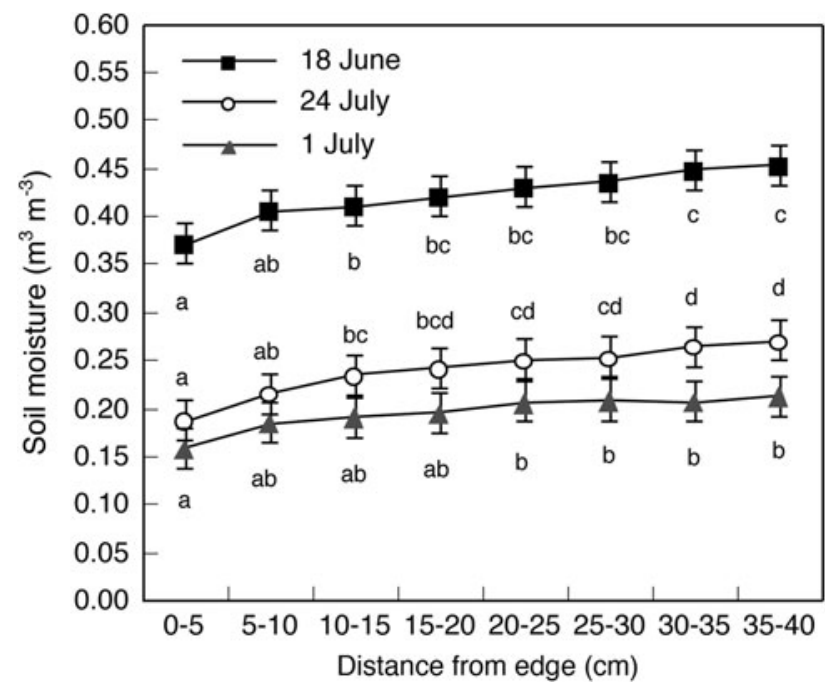

Fig. 1 Soil moisture across the edge-meadow transect $(0-40 \mathrm{~cm})$, measured on three different dates in $2008(n=17$, mean \pm SE). Different letters indicate significant differences at $p<0.05$

rain before 18 June, 6 days with rain before 1 July, and 7 days with rain before 24 July. Soil moisture decreased significantly towards the edge on all three measuring dates (ANOVA: 18 June: $F_{7,128}=9.73, p<0.001 ; 1$ July: $F_{7,128}$ $=3,43, p=0.002 ; 24$ July: $\left.F_{7,128}=16.41, p<0.001\right)$. At the edge, moisture averaged $20-30 \%$ less than in the meadow (Fig. 1). Soil was most moist on 18 June because water content was measured after the greatest number of days with rain. The edge to meadow soil moisture gradient was robust across a variety of weather conditions. Even the measuring series under rather wet conditions showed significantly drier edges.

Corresponding to the soil moisture gradient, vegetation height decreased significantly towards the edge $\left(F_{7,128}=\right.$ $5.34, p<0.001)$. Differences in height measured between 10 and $40 \mathrm{~cm}$ were not significant (Table 1); however, vegetation at the edge was $40 \%$ shorter than vegetation measured between 35 and $40 \mathrm{~cm}$. Total biomass did not differ significantly between the edge and the meadow $\left(F_{7,128}=1.84, p=\right.$ 0.08 ), although there was a trend for higher amounts of biomass in the meadow (Table 1). However, the amount of necromass nearly doubled (increase of $85 \%$ ) towards the edge $\left(F_{7,128}=3.86, p<0.001\right.$; Table 1$)$. Amounts of necromass observed between 15 and $40 \mathrm{~cm}$ were quite similar and only increased closest to the edge.

Species composition along the edge-meadow transect

In total, 100 plant species were found across all plots, with an average number of $23 \pm 6$ (mean $\pm \mathrm{SD}$ ) species on each transect. The number of species decreased significantly towards the edge (quadratic regression, $y=-0.0042 x^{2}+$ $\left.0.26 x+5.66 ; R^{2}=0.89, p<0.001\right)$. At the edge $(0-5 \mathrm{~cm})$, the average number of species was $6.2 \pm 1.7$, whereas in the meadow $(35-40 \mathrm{~cm}) 9.7 \pm 2.7($ mean $\pm \mathrm{SD})$ species were observed. The number of species at the edge was strongly positively correlated with the number of species in the adjacent meadow $(r=0.64, p=0.006)$. Species-rich meadows had a higher number of species occurring at the edge than species-poor meadows. The Jaccard index of similarity indicated that the vegetation within one plot (edge compared to meadow: $J=0.456 \pm 0.037$, mean $\pm \mathrm{SE}$ ) was significantly more similar than the vegetation among the edges of the different plots $(J=0.166 \pm 0.009 ; p<0.001)$.

The weighted means of the six Landolt indicator values differed significantly between edge and meadow (Fig. 2). Plants growing at the edge preferred drier conditions than plants in the meadow $(p=0.002)$, matching the lower soil moisture measured at the edge. Further, the species at the edge indicate slightly more acidic $(p<0.001)$ and nutrientpoorer soils $(p<0.001)$. Since plant nutrient availability decreases with low soil moisture, these two factors are presumably linked to each other (Marschner 1995). In addition, the Landolt values hint at significantly higher light demands $(p=0.026)$ and higher temperature preferences $(p=0.023)$ for edge species, possibly related to the more open, drier conditions at the edge. Also, thermal extremes are likely to be more pronounced at the edge, reflected in the higher Landolt value for continentality (the amplitude of temperature variation; $p<0.001$ ).

Sixteen species were more frequent at the edge than in the meadow (edge index above 0 ; Table $1 S$ ). Those species with edge preference were mostly species with either (1) rolled/ festucoid leaves, like Festuca spp., Avenella flexuosa, and Nardus stricta, or (2) species with small and/or scleromorphic leaves like Vaccinium vitis-idaea, Calluna vulgaris, Thymus spp., and Polygala chamaebuxus. Among those edge specialists, species like $V$. vitis-idaea and A. flexuosa had a very high edge index, but occurred in only 1 of the 17 plots. In contrast, the three Thymus species were much more abundant, but all three have comparatively low positive edge indices, i.e. did not show a very pronounced edge preference. The ecologically most important edge specialists were the three Festuca species, since there was at least one Festuca species present in each plot, and all of them showed high edge indices. Festuca valesiaca s.l., with the highest cover and a high edge index, represented the most dominant edge specialist of the landslide edges in the Ursern Valley. In contrast, 71 species with a "meadow preference" were largely missing from the edges. These 71 species are typical meadow species with varying types of growth forms.

Thirteen species had an edge index of 0 indicating they did not occur in either the edge or the meadow category. The fact that fewer species were identified with edge preferences corresponds well to the decreasing number of species as one approaches the edge. 
Table 1 Vegetation height, biomass and necromass (mean \pm SE) across the edge-meadow transect

\begin{tabular}{|c|c|c|c|c|c|c|c|c|}
\hline & \multicolumn{8}{|c|}{ Distance to edge $(\mathrm{cm})$} \\
\hline & $0-5$ & $5-10$ & $10-15$ & $15-20$ & $20-25$ & $25-30$ & $30-35$ & $35-40$ \\
\hline Vegetation height $(\mathrm{cm})$ & $14.8 \pm 1.4 \mathrm{a}$ & $17.8 \pm 1.6 \mathrm{ab}$ & $20.1 \pm 1.3 b c$ & $22.0 \pm 1.4 b c$ & $21.4 \pm 1.7 \mathrm{bc}$ & $23.2 \pm 1.8 \mathrm{bc}$ & $24.1 \pm 2.0 \mathrm{bc}$ & $25.3 \pm 1.9 \mathrm{c}$ \\
\hline Biomass $\left(\mathrm{g} \mathrm{m}^{-2}\right)$ & $\begin{array}{l}334 \pm 36 \\
\text { n.s. }\end{array}$ & $279 \pm 29$ & $333 \pm 33$ & $290 \pm 19$ & $315 \pm 26$ & $311 \pm 19$ & $359 \pm 28$ & $398 \pm 30$ \\
\hline Necromass $\left(\mathrm{g} \mathrm{m}^{-2}\right)$ & $198 \pm 23 \mathrm{a}$ & $129 \pm 16 \mathrm{ab}$ & $149 \pm 18 \mathrm{ab}$ & $111 \pm 17 \mathrm{~b}$ & $108 \pm 16 b$ & $115 \pm 14 \mathrm{~b}$ & $103 \pm 14 b$ & $107 \pm 11 \mathrm{~b}$ \\
\hline
\end{tabular}

Different letters indicates significant differences at $p<0.05$

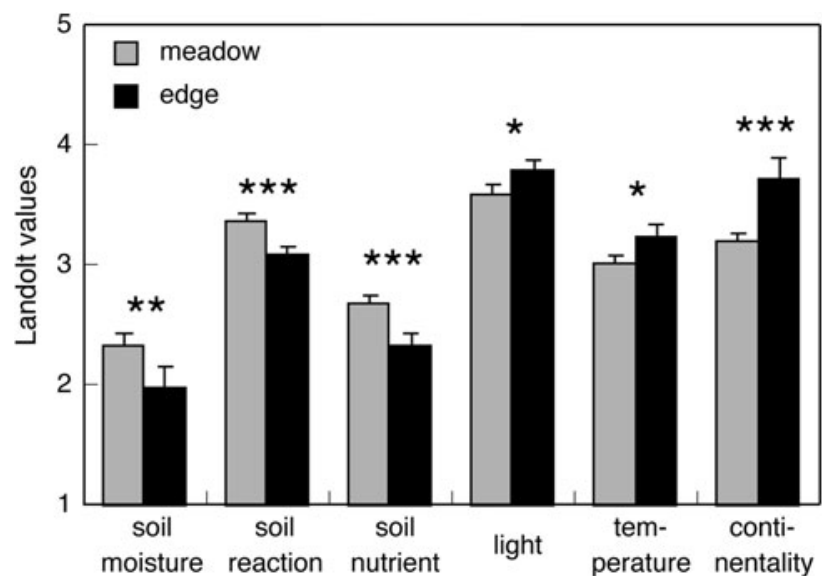

Fig. 2 Landolt's ecological indicator values (weighted means for each plot, $n=17$, mean $\pm 1 \mathrm{SE}$ ). 1 indicating low demands, 5 indicating high demands for a factor $(* * * p<0.001 ; * * p<0.01$; $* p<0.050)$

Cover of graminoids with rolled/festucoid leaves increased with increasing proximity to the edge and was 14 times higher at the edge than it was in the meadow (Fig. 3). However, $69 \%$ fewer graminoid species occurred with non-rolled leaves (Poaceae, Cyperaceae, Juncaceae) at the edge compared to the number observed in the meadow. The area covered by forbs also decreased towards the edge, with $78 \%$ fewer non-N-fixing, and $88 \%$ fewer $\mathrm{N}$-fixing forbsat the edge relative to species numbers counted in the meadow (e.g., Trifolium pratense, and Lotus corniculatus ssp. hirsutus were widespread in the meadow, but not at the edge). Cover of dwarf shrubs (except for the species with small/scleromorphic leaves), thoughdecreased slightly from meadow to edge. In the densely covered meadow, no bare soil was observed, whereas bare soil comprised about $5 \%$ of the total area at the edge (Table 2).

Response of the three most abundant species

As the most prominent representative of the functional group "graminoids with rolled/festucoid leaves", the cover of Festuca valesiaca s.l. increased exponentially towards the edge (exponential regression; $R^{2}=0.95, p<0.001$;
Fig. 4). Cover of Festuca valesiaca s.l. was 11 times higher at the edge compared to the meadow. Since it was the most frequent graminoid with rolled/festucoid leaves, this species contributed substantially to the 14-times increase of the graminoids with rolled/festucoid leaves. The distribution across the edge-meadow transect of the two other most abundant species showed an opposite pattern (Fig. 4). Cover of Brachypodium pinnatum decreased by $79 \%$ towards the edge (quadratic regression; $R^{2}=0.94, p<$ 0.001 ) and varied more in the meadow. The less frequent Agrostis gigantea decreased by $33 \%$ towards the edge (quadratic regression; $R^{2}=0.64, p<0.001$ ). This reduced abundance of $B$. pinnatum and $A$. gigantea, two grasses with non-rolled leaves, corresponds to the overall decrease of graminoids with non-rolled leaves. Biomass data of the three species Festuca valesiaca s.l., B. pinnatum, and A. gigantea were closely related to the vegetation cover data (Fig. 4).

All three species had significantly shorter leaves at the edge compared to the meadow (Table 3): leaves of Festuca valesiaca s.l. were $38 \%(p<0.001)$, of $B$. pinnatum $39 \%$ $(p<0.001)$ and of A. gigantea about $14 \%$ shorter at the edge compared to the meadow $(p=0.024)$.

Leaf $\delta^{13} \mathrm{C}$ values were not significantly different between edge and meadow for all three species (Festuca valesiaca s.1.: $p=0.20 ; B$. pinnatum: $p=0.68 ;$ A. gigantea: $p=0.52$; Table 3 ). $\delta^{13} \mathrm{C}$ means of Festuca valesiaca s.l. and $A$. gigantea were only slightly less negative at the edge compared to the meadow.

\section{Discussion}

The central aims of this study were to characterize the life conditions at the edges of landslides, to identify edge specialist species and their traits that potentially reduce further erosion, and to clarify the influence of the adjacent meadows as a species pool for colonization (primary succession on eroded edges). We observed a clear change of species composition from the meadow towards the edges of landslides. The species occurring at the edge were characterized by higher tolerance to dry soils with presumably 
Fig. 3 Cover (\%) of different plant functional types and bare soil across the edge-meadow transect $(0-40 \mathrm{~cm}$ long, $1.60 \mathrm{~m}$ wide)

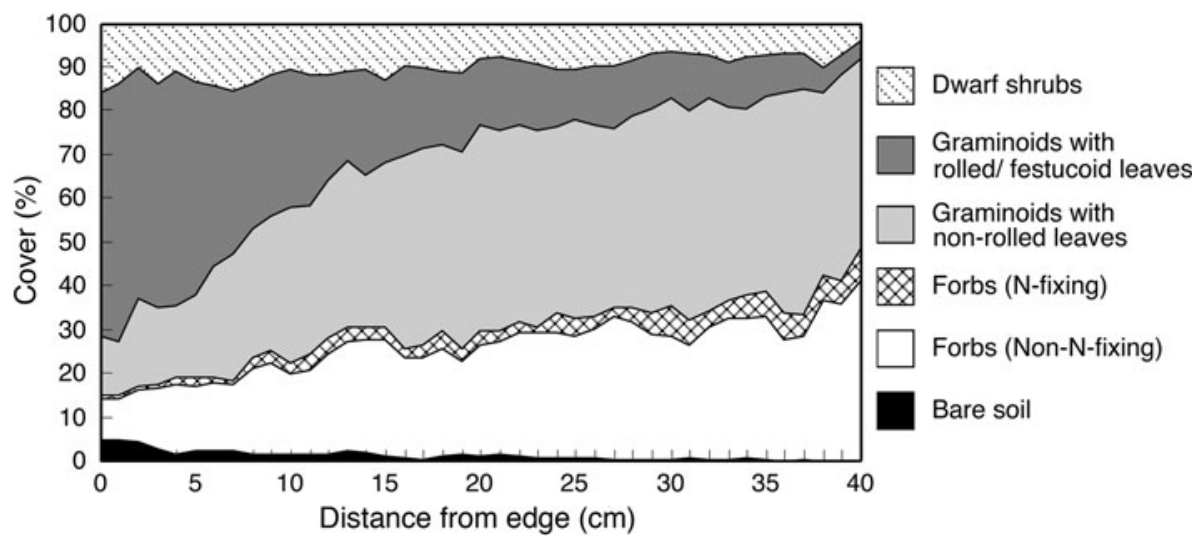

Table 2 Regressions of the cover (\%) of plant functional types and bare soil across the edge-meadow transect $(0-40 \mathrm{~cm})$

\begin{tabular}{lllr}
\hline Functional group & Model & Regression & $R^{2}$ \\
\hline Dwarf shrubs & Linear regression & $y=-0.19 x+13.69$ & 0.70 \\
Graminoids with rolled/festucoid leaves & Exponential regression & $y=54.73-0.056 x$ & $<0.001$ \\
Graminoids with non-rolled leaves & Quadratic regression & $y=-0-039 x^{2}+2.35 x+12.40$ & 0.94 \\
Forbs & Linear regression & $y=0.58 x+13.26$ & $<0.001$ \\
N-fixing forbs & Linear regression & $y=0.12+0.92$ & $<0.001$ \\
Bare soil & Linear regression & $y=-0.085 x+3.07$ & $<0.001$ \\
\hline
\end{tabular}

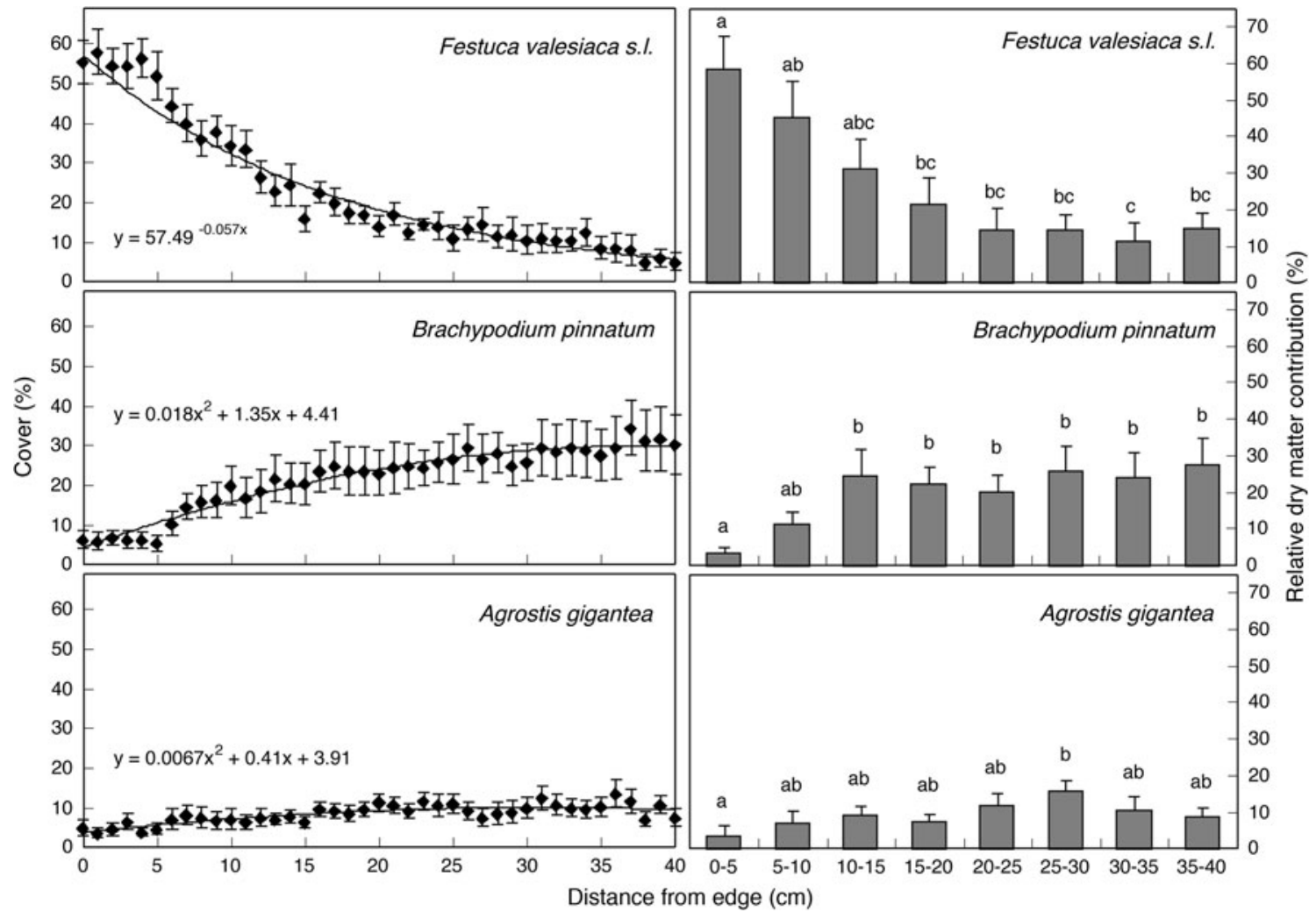

Fig. 4 Cover and relative contribution of the three most abundant grass species to total biomass across the edge-meadow transect (mean $\pm 1 \mathrm{SE}$ ). Different letters indicate significant differences at $p<0.05$ 
Table 3 Leaf length and leaf $\delta^{13} \mathrm{C}$ values (mean \pm SE) of the three most abundant grass species

\begin{tabular}{|c|c|c|c|c|c|c|}
\hline & \multicolumn{3}{|c|}{ Leaf length $(\mathrm{cm})$} & \multicolumn{3}{|l|}{ Leaf $\delta^{13} \mathrm{C}$} \\
\hline & $\begin{array}{l}\text { Meadow } \\
>35 \mathrm{~cm}\end{array}$ & $\begin{array}{l}\text { Edge } \\
0-10 \mathrm{~cm}\end{array}$ & $p$ value & $\begin{array}{l}\text { Meadow } \\
>35 \mathrm{~cm}\end{array}$ & $\begin{array}{l}\text { Edge } \\
(0-10 \mathrm{~cm})\end{array}$ & $p$ value \\
\hline Festuca valesiaca s.l. & $24.4 \pm 0.9$ & $15.0 \pm 0.9$ & $<0.001$ & $-27.48 \pm 0.16$ & $-27.20 \pm 0.18$ & n.s. \\
\hline Brachypodium pinnatum & $26.6 \pm 1.9$ & $16.1 \pm 1.1$ & $<0.001$ & $-27.42 \pm 0.11$ & $-27.50 \pm 0.19$ & n.s. \\
\hline Agrostis gigantea & $10.3 \pm 0.7$ & $8.9 \pm 0.6$ & $<0.05$ & $-29.11 \pm 0.15$ & $-28.90 \pm 0.25$ & n.s. \\
\hline
\end{tabular}

low nutrient availability and to higher radiation and temperature variation (Fig. 2). The soil moisture measurements across edge-meadow transects confirmed that the edges were significantly drier than the meadow, even after long rainy periods (Fig. 1). Low nutrient availability, dry soil, and high insolation were closely interrelated (Marschner 1995; Larcher 2003), and a likely cause of this change in species composition towards the edge.

The increase in necromass and the decrease in vegetation height towards the edge (Table 1) suggest a direct impact of edge conditions on plant composition, plant size, and delayed decay. However, the lack of change in total biomass across the gradient implies a preference for lower stature species at the edge. The prostrate growth of Thymus and other dwarf shrubs is a typical example. Likewise, the high amount of necromass at the edge can be explained by the high abundance of Festuca species, intrinsically forming necromass-rich tussocks.

Shorter leaves produced by Festuca valesiaca s.1., Brachypodium pinnatum, and Agrostis gigantea at the edge compared to those produced by these species growing in the meadow (Table 3) indicates water limitation of leaf expansion at the edge (Hsiao 1973; Busso and Richards 1993; Sadras and Milroy 1996; De Abelleyra et al. 2008). However, the $\delta^{13} \mathrm{C}$ signals did not indicate that the tissues harvested at the edge were synthesized from assimilates fixed under drought stress (Fig. 3). Leaf $\delta^{13} \mathrm{C}$ is directly related to stomatal behavior and, hence, to drought stress during photo-assimilation (Farquhar et al. 1989). Shorter leaves of otherwise unchanged ${ }^{13} \mathrm{C}$ discrimination leads us to assume that species selected for life at the edge avoided drought stress during photo-assimilation and terminated leaf production when it became too dry, thus retaining no clear ${ }^{13} \mathrm{C}$ fingerprint.

The decreasing number of species observed towards the edge, and the change of the relative abundance within species (Fig. 4), thusled to the dominance of a few specialist species. The common features of these "successful" species at the edge, like rolled or festucoid leaves and small as well as scleromorphic leaves, are adaptations to cope with dry conditions, since water loss is reduced and heat convection is maximized by minimizing the transpiring surface (Redmann 1985; Larcher 2003). Further, the species dominating the edges are known to have fibrous, extensive root systems that penetrate and reinforce the soil (Styczen and Morgan 1995; De Baets et al. 2006). The species that occur more frequently at the edge than in the meadow can be seen as "edge engineers" by mitigating or even halting further erosion, since any erosion progression was not observed at the selected edges during the study year or in the following years, and thus the edges tend to remain stable (C. Huck and E. Hiltbrunner, personal observations). Our results corroborate earlier observations that grasses of the genus Festuca contribute to the stability of erosion edges (Wicherek 1993; Ruemmele et al. 2003; Grashey-Jansen 2012). For instance, in a laboratory experiment on bare slopes, grass strips formed by Festuca ovina yielded less soil loss compared with grass strips of Poa pratensis, which was mainly explained by greater root density, but also by the interwoven nature of Festuca leaves and stems (Tadesse and Morgan 1996). In the present study, $F$. ovina also preferred edges with an edge index of 0.53 , but was present in only two plots. In a recent survey on erosion gullies in dry grassland and reforested woodland of the inneralpine Vinschgau valley, GrasheyJansen (2012) reported that soil surfaces in the grassland were predominantly stabilized by $F$. valesiaca. Landslides have recurred in the Vinschgau valley since the nineteenth century, not permitting the delineation of the precise age of the erosion gullies.

Since $F$. valesiaca s.l. occurs much more frequently at the landslide erosion edges in the Ursern Valley than any other plant, we propose this species as a potential keystone species, even this function has not been established so far (Bond 1993; Mills et al. 1993). Concerning the estimated age of the landslides of 4-6 years, Festuca valesiaca s.l., although known as rather slow growing species, is capable of establishing on initially unstable ground and dominating landslide edges within a period of c. 5 years only.

In addition, young seedlings of $F$. valesiaca s.l. survived better on overheated soil surfaces than other Festuca species (F. rupicola) in xerothermic grassland (Hroudova-Pucelikova 1972). Thus, seedling establishment of this Festuca species seems not to be restricted due to the dryness at the edges. 
In line with our study, a Festuca species also belonging to the $F$. valesiaca aggregate was found to dominate the edges of erosion gullies in the Central Caucasus (Caprez et al. 2011). Lower precipitation and the more continental climate in this region resulted in leaves of $F$. valesiaca enriched in ${ }^{13} \mathrm{C}$ (less negative) at the gully edges, indicating water shortage not seen in our study during biomass/ leaf formation.

Hence, Festuca valesiaca s.1. may play a key role in stabilizing erosion edges in a wide array of mountain grasslands. Festuca valesiaca s.l. is not a very abundant species in undisturbed meadows in either the Swiss Alps or in the Central Caucasus, (e.g., Klötzli et al. 2010). The dominant role of this species only emerges after disturbance. Keystone species contribute to ecosystem functioning in ways that are unique. Thus, their loss or addition causes detectable changes in ecosystem functioning (Bond 1993; Power et al. 1996; Naeem et al. 2002). Despite the common presence of Festuca valesiaca s.l. at erosion edges, in its absencethere are some other species that could exert similar functions of an edge-engineer with a fibrous root system, e.g. Festuca rubra or Avenella flexuosa (Ruemmele et al. 2003). Such functional redundancy enhances ecosystem reliability and guarantees long-term functional diversity (Walker 1992; Joner et al. 2011). According to the insurance hypothesis, biodiversity insures ecosystem functions in a fluctuating environment (Yachi and Loreau 1999), thuspreventing complete system failure (Körner 2004). The insurance mechanism is commonly assumed to enhance temporal stability by covariation in species abundance over time (Tilman 1999, Lehmann and Tilman 2000). In our study, erosion edges surrounded by species-rich meadows were shown to have a higher plant diversity than edges surrounded by species-poorer meadows, thus stressing the importance of species composition and biodiversity of the meadows for the long-term stability of erosion edges. Human land use is among the most important determinants of grassland biodiversity (e.g., Fischer et al. 2008; Zimmermann et al. 2010). In the Ursern Valley, as in many mountain regions, an intensification of easily accessible areas and a concurrent extensification of remote areas have been observed in recent decades (Tasser and Tappeiner 2002; Gellrich et al. 2007; Galvanek and Leps 2008). Festuca valesiaca s.l. is likely to disappear both under intensification (fertilizer application in particular) and by complete abandonment through subsequent encroachment by taller or woody taxa. This plant species is a typical representative that profits from intermediate disturbance (extensive land use) which is also known to facilitate maximum biodiversity (Petraitis et al. 1989; Hobbs and Huenneke 1992). Its potential keystone role, however, remains hidden, until an extreme event such as landslide erosion makes it an emergent property. This study points to the importance of local species richness for ensuring the availability of a pool of plant species from which keystone species can be drawn in case of "emergency".

Acknowledgments We thank the "Korporation Ursern" and the farmers of the Ursern Valley for their support and cooperation in this study. We also thank Rolf Siegwolf and his team in the PSI for the $\delta^{13} \mathrm{C}$ analysis. We are grateful to Christophe Bornand for his ideas and for reading a previous version of this manuscript. This project contributes to the Swiss National Research (SNR) project CR30I3_124809, acronym VALUrsern.

\section{References}

Allen-Diaz BH (1991) Water-table and plant-species relationships in Sierra-Nevada meadows. Am Midl Nat 126:30-43

Auerswald K (1998) Gravitative Bodenverlagerung. In: Richter G (ed) Bodenerosion analyse und Bilanz eines Umweltproblems. Wissenschaftl Buchgesellschaft, Darmstadt, pp 61-68

Binz A, Heitz C (1990) Schul- und Exkursionsflora für die Schweiz, mit Berücksichtigung der Grenzgebiete Bestimmungsbuch für die wildwachsenden Gefässpflanzen, 19. Aufl. 100-107. Tsd. edn. Schwabe, Basel

Bond WJ (1993) Keystone species. Biodivers Ecosys Funct 99:237253

Bonham D (1989) Measurements for terrestrial vegetation. Wiley, New York

Busso CA, Richards JH (1993) Leaf extension rates in two tussock grasses: effects of water stress and clipping. Acta Oecol 14:3-15

Caldeira MC, Ryel RJ, Lawton JH, Pereira JS (2001) Mechanisms of positive biodiversity-production relationships: insights provided by delta C-13 analysis in experimental Mediterranean grassland plots. Ecol Lett 4:439-443

Caprez R, Spehn E, Nakhutsrishvili G, Körner C (2011) Drought at erosion edges selects for a 'hidden' keystone species. Plant Ecol Divers. doi:10.1080/17550874.2011.600343

Chambers JC (1995) Disturbance, life-history strategies, and seed fates in alpine herbfield communities. Am J Bot 82:421-433

Chambers JC, Macmahon JA, Brown RW (1990) Alpine seedling establishment-the influence of disturbance type. Ecology 71:1323-1341

Chaudhry S, Singh SP, Singh JS (1996) Performance of seedlings of various life forms on landslide-damaged forest sites in Central Himalaya. J Appl Ecol 33:109-117

Dawson TE, Mambelli S, Plamboeck AH, Templer PH, Tu KP (2002) Stable isotopes in plant ecology. Annu Rev Ecol Syst 33:507-559

De Abelleyra D, Verdu AMC, Kruk BC, Satorre EH (2008) Soil water availability affects green area and biomass growth of Cynodon dactylon. Weed Res 48:248-256

De Baets S, Poesen J, Gyssels G, Knapen A (2006) Effects of grass roots on the erodibility of topsoils during concentrated flow. Geomorphology 76:54-67

De Baets S, Poesen J, Reubens B, Wemans K, De Baerdemaeker J, Muys B (2008) Root tensile strength and root distribution of typical Mediterranean plant species and their contribution to soil shear strength. Plant Soil 305:207-226

Farquhar GD, Ehleringer JR, Hubick KT (1989) Carbon isotope discrimination and photosynthesis. Annu Rev Plant Physiol Plant Mol Biol 40:503-537

Fattet M, Fu Y, Ghestem M, Ma W et al (2011) Effects of vegetation type on soil resistance to erosion: relationship between aggregate stability and shear strength. Catena 87:60-69 
Fischer M, Rudmann-Maurer K, Weyand A, Stöcklin J (2008) Agricultural land use and biodiversity in the Alps-how cultural tradition and socioeconomically motivated changes are shaping grassland biodiversity in the Swiss Alps. Mt Res Dev 28:148-155

Galvanek D, Leps J (2008) Changes of species richness pattern in mountain grasslands: abandonment versus restoration. Biodivers Conserv 17:3241-3253

Gellrich M, Baur P, Koch B, Zimmermann NE (2007) Agricultural land abandonment and natural forest re-growth in the Swiss mountains: a spatially explicit economic analysis. Agric Ecosyst Environ 118:93-108

Grashey-Jansen S (2012) Soil hydrology and soil properties on a partially reforested hillside in the Central Alps. J For Sci 58:363-371

Gyssels G, Poesen J, Bochet E, Li Y (2005) Impact of plant roots on the resistance of soils to erosion by water: a review. Progr Phys Geogr 29:189-217

Hobbs RJ, Huenneke LF (1992) Disturbance, diversity, and invasion: implications for conservation. Conserv Biol 6:324-337

Hroudova-Pucelikova Z (1972) A comparative study of the ecology of Festuca valesiaca Gaudon and Festuca rupicola Heuff. Folia Geobot Phytotax 7:53-79

Hsiao TC (1973) Plant responses to water stress. Annu Rev Plant Physiol Plant Mol Biol 24:519-570

Jaccard P (1908) Nouvelles recherches sur la distribution florale. Bull Soc Vaudoise Sci Nat 44:223-270

Joner F, Specht G, Müller SC, Pillar VD (2011) Functional redundancy in a clipping experiment on grassland plant communities. Oikos 120:1420-1426

Kägi HU (1973) Die traditionelle Kulturlandschaft im Urserental Beitrag zur alpinen Kulturgeographie. Doctoral thesis. Zurich

Klötzli F, Dietl W, Marti K et al (2010) Vegetation Europas: Das Offenland im vegetationskundlich-ökologischen Überblick. Ott, Bern

Kluse JS, Diaz BHA (2005) Importance of soil moisture and its interaction with competition and clipping for two montane meadow grasses. Plant Ecol 176:87-99

Körner C (1993) Scaling from species to vegetation-the usefulness of functional groups. Biodivers Ecosys Funct 99:117-140

Körner C (2004) Mountain biodiversity, its causes and function. Ambio 13:11-17

Küttel M (1990a) Der subalpine Schutzwald im Urserental-ein inelastisches Ökosystem. Bot Helv 100/2

Küttel M (1990b) Zur Vegetationsgeschichte des Gotthardgebietes. Mitt Naturforsch Ges Luzern 31:110-111

Landolt E (1977) Oekologische Zeigerwerte zur Schweizer Flora. Veröffentlichungen des Geobotanischen Institutes der ETH, Zürich

Larcher W (2003) Physiological plant ecology ecophysiology and stress physiology of functional groups, 4 th edn. Springer, Berlin

Lehmann CL, Tilman D (2000) Biodiversity, stability and productivity in competitive communities. Am Nat 156:534-552

Loreau M, Hector A (2001) Partitioning selection and complementarity in biodiversity experiments. Nature 412:72-76

Loreau M, Naeem S, Inchausti P et al (2001) Biodiversity and ecosystem functioning: current knowledge and future challenges. Science 294:804-808

Maquaire O, Malet J-P (2006) Shallow landsliding. In: Boardman J, Poesen J (eds) Soil erosion in Europe. Wiley, Chichester, pp 583-598

Marschner H (1995) Mineral nutrition of higher plants. Academic, London

Meteo-Schweiz (1990-2007) Gütsch, above Andermatt. URL http:// www.meteoschweiz.ch (access date 10.11.2008)
Meusburger K, Alewell C (2008) Impacts of anthropogenic and environmental factors on the occurrence of shallow landslides in an alpine catchment (Urseren Valley, Switzerland). Nat Hazards Earth Syst Sci 8:1-12

Mills LS, Soulé ME, Doak DF (1993) The keystone-species concept in ecology and conservation. Bioscience 43:219-224

Morgan RPC (2005) Soil erosion and conservation, 3rd edn. Blackwell, Cornwall

Naeem S, Bunker DE, Hector A, Loreau M, Perrings C (eds) (2009) Biodiversity, ecosystem functioning and human wellbeing. An ecological and economic perspective. Oxford University Press, Oxford

Naeem S, Thompson LJ, Lawler SP, Lawton JH, Woodfin RM (1995) Empirical evidence that declining species diversity may alter the performance of terrestrial ecosystems. Philos Trans R Soc Lond B 347:249-262

Naeem S, Loreau M, Inchausti P (2002) Biodiversity and ecosystem functioning: the emergence of a synthetic ecological framework. In: Loreau M, Naeem S, Inchausti P (eds) Biodiversity and ecosystem functioning synthesis and perspectives. Oxford University Press, Oxford, p 294

Nagel R (2009) Vegetation succession and seed bank composition on regenerating landslides in the Swiss Central Alps. Diploma thesis. University of Kiel

Petraitis PS, Latham RE, Niesenbaum RA (1989) The maintenance of species diversity by disturbance. Q Rev Biol 64:393-418

Pohl M, Alig D, Korner C, Rixen C (2009) Higher plant diversity enhances soil stability in disturbed alpine ecosystems. Plant Soil 324:91-102

Pohl M, Stroude R, Buttler A, Rixen C (2011) Functional traits and root morphology of alpine plants. Ann Bot 108:537-545

Power ME, Tilman D, Estes J et al (1996) Challenges in the quest for keystones. Bioscience 46:609-620

Proulx R, Wirth C, Voigt W et al (2010) Diversity promotes temporal stability across levels of ecosystem organization in experimental grasslands. PLoS ONE 5(10):e13382. doi:10.1371/journal.pone. 0013382

Redmann RE (1985) Adaptation of grasses to water stress-leaf rolling and stomate distribution. Ann Miss Bot Gard 72:833-842

Reubens B, Poesen J, Danjon F, Geudens G, Muys B (2007) The role of fine and coarse roots in shallow slope stability and soil erosion control with a focus on root system architecture: a review. Trees Struct Funct 21:385-402

Rickli C, Graf F (2009) Effects of forests on shallow landslides-case studies in Switzerland. For Snow Landsc Res 82:33-44

Ruemmele BA, Wipff JK, Brilman L, Hignight KW (2003) Fine-leaves Festuca species. In: Casler MD, Duncan RR (eds) Turfgrass biology, genetics, and breeding. Wiley, New York, pp 129-174

Sadras VO, Milroy SP (1996) Soil-water thresholds for the responses of leaf expansion and gas exchange: a review. Field Crops Res 47:253-266

Stokes A, Atger C, Bengough AG, Fourcaud T, Sidle RC (2009) Desirable plant root traits for protecting natural and engineered slopes against landslides. Plant Soil 324:1-30

Styczen ME, Morgan RPC (1995) Engineering properties of vegetation. In: Morgan RPC, Rickson RJ (eds) Slope stabilization and erosion control a bioengineering approach. E und FN Spon, London, pp 5-58

Swisstopo (2006) Reproduziert mit Bewilligung von swisstopo, BA071108, Zürich

Tadesse LD, Morgan RPC (1996) Contour grass strips: a laboratory simulation of their role in erosion control using live grasses. Soil Technol 9:83-89

Tasser E, Tappeiner U (2002) Impact of land use changes on mountain vegetation. Appl Veg Sci 5:173-184 
R Development Core Team (2008) R: a language and environment for statistical computing. In: R Foundation for Statistical Computing, Vienna, Austria, URL http://www.R-project.org

Tilman D (1999) The ecological consequences of changes in biodiversity: a research for general principles. Ecology 80: $1455-1474$

Tilman D, Downing JA (1994) Biodiversity and stability in grasslands. Nature 367:363-365

Walker BH (1992) Biodiversity and ecological redundancy. Conserv Biol 6:18-23

Walker LR, Shiels AB (2008) Post-disturbance erosion impacts carbon fluxes and plant succession on recent tropical landslides. Plant Soil 313:205-216
Wicherek S (1993) Farm land erosion: in temperate plains environment and hills. In: Proceedings of International Symposium on Farm Land Erosion, Paris, Saint-Cloud, France, 25-29 May 1992, Elsevier, Amsterdam

Wohl DL, Arora S, Gladstone JR (2004) Functional redundancy supports biodiversity and ecosystem function in a closed and constant environment. Ecology 85:1534-1540

Yachi S, Loreau M (1999) Biodiversity and ecosystem productivity in a fluctuating environment: the insurance hypothesis. Proc Natl Acad Sci USA 96:1463-1468

Zimmermann P, Tasser E, Leitinger G, Tappeiner U (2010) Effects of land-use and land-cover pattern on landscape-scale biodiversity in the European Alps. Agric Ecosyst Environ 139:13-22 